\title{
Differential Intracellular Calcium Responses to Glutamate in Type 1 and Type 2 Cultured Brain Astrocytes
}

\author{
Abbie M. Jensen ${ }^{1}$ and S. Y. Chiu ${ }^{2}$ \\ 'Neuroscience Training Program and 'Department of Neurophysiology, University of Wisconsin, Madison, Wisconsin 53706
}

Fluorescence image analysis using the calcium indicator fluo-3 was used to examine changes in $\left[\mathrm{Ca}^{2+}\right]_{i}$ induced by glutamate in mixed glia populations cultured from neonatal rat brains. $\left[\mathrm{Ca}^{2+}\right]$, responses were correlated with glia type by performing immunohistochemistry using markers specific for type 1 and type 2 astrocytes on the same cells used in the imaging experiments. Glutamate (30-500 $\mu \mathrm{M})$ induced two markedly different $\left[\mathrm{Ca}^{2}{ }^{2}\right]$, responses in the two astrocyte types: the response in type 1 astrocytes consisted of an initial fast transient followed by varying degrees of oscillations, whereas the predominant response in type 2 astrocytes was a slow rise in $\left[\mathrm{Ca}^{2+}\right]$, to a more or less sustained and nonoscillatory level. In some type 2 astrocytes, an initial spikelike transient similar to that in type 1 astrocytes was observed; the overall size of the spike, however, was smaller than in type 1 astrocytes. Two agonists for the ionotropic glutamate receptor, $\alpha$-amino-3-hydroxy-5-methylisoxazole4-propionate (AMPA) and kainate, elicited a 6-cyano-7-dinitroquinoxaline-2,3-dione (CNQX)-sensitive, external $\mathrm{Ca}^{2+}$

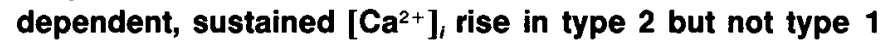
astrocytes. The initial spike in type 2 astrocytes was less dependent on external $\mathrm{Ca}^{2+}$ and not blocked by $\mathrm{CNQX}$. $\left[\mathrm{Na}^{+}\right]_{\text {, }}$ as measured by the $\mathrm{Na}^{+}$-fluorescence dye SBFI, was elevated by kainate in both astrocyte types, though the increase was larger in type 2 astrocytes. This increase was reduced by CNQX, suggesting this $\left[\mathrm{Ca}^{2+}\right]$; increase was mediated, at least in part, by ionotropic glutamate receptors. The results are discussed in terms of the relative distribution of two classes of glutamate receptors on these two astrocyte types: one, the ionotropic class, is linked directly to an ion channel, and the other, the metabotropic class, induces internal mobilization of $\mathrm{Ca}^{2+}$ via inositol phospholipid hydrolysis.

Neurotransmitter receptors coupled to second messengers, as well as ligand- and voltage-gated ion channels, are membrane proteins employed by the CNS, notably in neurons, for signal processing. While brain signaling has been described in terms of neurons, recent studies have provided mounting evidence that these membrane proteins also are a property shared with

\footnotetext{
Received Sept. 6, 1990; revised Jan. 15, 1991; accepted Jan. 18, 1991.

We wish to thank C. K. Chang for software assistance in image analysis and Carol Dizack and Terry Stewart for help in illustration and photography. This work was supported in part by U.S. Public Health Service Grant NS-23375, by U.S. National Multiple Sclerosis Society Grant RG-1839, and by a Pew Scholar award in the biomedical sciences to S.Y.C.

Correspondence should be addressed to S. Y. Chiu, University of Wisconsin, Department of Neurophysiology, 283 Medical Sciences Building, 1300 University Avenue, Madison, WI 53706.

Copyright (C) 1991 Society for Neuroscience $0270-6474 / 91 / 1$ I 1674-11\$03.00/0
}

glia, another major cellular component in the brain that outnumbers neurons 10:1 and forms one-half of the brain volume (Kuffler et al., 1984). First evidence came from studies of glia in vitro (see reviews by Pearce and Murphy, 1988; Barres et al., 1990 a). Further, evidence that glia express many of these membrane proteins in vivo is emerging. In situ hybridization histochemistry using probes from cloned glutamate receptors revealed the presence of messages in putative Bergmann glia in cerebellar sections (Keinanen et al., 1990), corroborating a similar conclusion drawn from studies using an antibody against a kainate (KA)-binding protein (Somogyi et al., 1990), and patchclamp studies have revealed ligand- and voltage-gated ion channels in freshly isolated glia and glia precursors (Barres et al., 1989,1990 b). Indeed, brain glia may be as dynamically regulated as neurons, as illustrated by the developmental plasticity of ion channel and receptor properties (Gallo et al., 1989; Sontheimer et al., 1989; Barres et al., 1990b), glia-type-dependent expression of ion channels (Barres et al., 1990a), and regional heterogeneity (Wilkin et al., 1990).

Astrocytes are, by and large, the most abundant glia type. Classically, astrocytes in vivo have been classified into two major types, the protoplasmic type present in gray matter, and the fibrous type present in white matter. In vitro studies of the rat optic nerve (Rafl, 1989) resulted in the characterization of two astrocytes that differ in cell lineage, in their interactions with other CNS cells (type 1 astrocytes form the glial limiting membrane and send end feet to blood vasculature, while the role of type 2 astrocytes is unknown), in antigenicity, and in ion channel properties (Barres et al., 1990a). While it is unclear how the in vitro classification corresponds with in vivo classification, type 1 and type 2 astrocytes, collectively, provide a powerful in vitro system for exploring glial role in brain function and development.

This article examines $\left[\mathrm{Ca}^{2+}\right]_{i}$ signaling induced in these two astrocyte types by an important CNS neurotransmitter, glutamate. Ligand-induced signaling often is characterized by cascades of intracellular second messengers (like IP3 and $\mathrm{Ca}^{2+}$ ), allowing a single stimulus to diverge into multiple cellular responses. In particular, $\left[\mathrm{Ca}^{2+}\right]_{i}$ signaling, which is often distinct between cell types and could even be regionally specialized within a single cell, now can be temporally and spatially resolved using calcium indicators and image analysis. Inferences on function and receptor properties can be made by examining different features of $\left[\mathrm{Ca}^{2+}\right]_{i}$ signaling. In recent studies on type 1 astrocyteenriched cultures, the observed kinetics of a glutamate-induced $\left[\mathrm{Ca}^{2+}\right]_{i}$ response are consistent with these cells expressing a class of glutamate receptor that is coupled to the IP3 second-messenger system (Cornell-Bell et al., 1990; Jensen and Chiu, 1990), 
and the spatial variation of $\left[\mathrm{Ca}^{2+}\right]_{i}$ has led to the suggestion of gap-junction-mediated long-range glial signaling (Cornell-Bell et al., 1990). Little is known about excitatory amino acid-induced $\left[\mathrm{Ca}^{2+}\right]_{i}$ signaling in type 2 astrocytes. In this article, we present a detailed comparison of glutamate-induced $\left[\mathrm{Ca}^{2+}\right]_{i}$ responses in type 1 and type 2 astrocytes in the same coculture.

\section{Materials and Methods}

\section{Materials}

Excitatory amino acids (L-glutamic acid, kainic acid) were purchased from Sigma (St. Louis, MO). Antagonist [6-cyano-7-dinitroquinoxaline2,3-dione (CNQX)] was purchased from Cambridge Research Biochemicals. The acetomethoxyester (AM) forms of the calcium indicator fluo-3 (fluo-3/AM) and the sodium indicator SBFI/AM were purchased from Molecular Probes (Junction City, OR). Tissue culture media and fetal bovine serum were obtained from Gibco (Grand Island, NY). Tissue culture reagents and primary polyclonal rabbit IgG antibody to glial fibrillary acidic protein (GFAP) were purchased from Sigma. A2B5 antibody supernatant (American Type Culture Collection, generously provided by Barbara Barres) was used at a dilution of 1:2. The GFAP primary antibody was viewed with a fluorescein (FITC)-conjugated $\mathrm{F}\left(\mathrm{ab}^{\prime}\right)_{2}$-fragment goat anti-rabbit $\mathrm{IgG}$ secondary antibody, purchased from Sigma. The A2B5 primary antibody was viewed with a rhodamine (Rd)-conjugated $\mathrm{F}\left(\mathrm{ab}^{\prime}\right)_{2}$ goat anti-mouse IgG secondary antibody, purchased from Accurate Chemical (Westbury, NY).

\section{Cell cultures}

Cerebral cortices plus part of the underlying white matter from postnatal day 2 rats (Sprague-Dawley) were stripped of the meninges and cut into small pieces, then gently triturated through an 18-gauge syringe needle to yield a cell suspension. The cells were filtered through a $60-\mu \mathrm{m}$ Nitex mesh (Tetko, Elmsford, NY), pelleted by gentle centrifugation ( $5 \mathrm{~min}$, $400 \times g$ ), resuspended, and plated onto $75-\mathrm{cm}^{2}$ T-flasks. Cells first were grown to confluence $(\approx 7 \mathrm{~d})$ in Dulbecco's modified Eagle's medium containing $10 \%$ fetal bovine serum, insulin $(10 \mu \mathrm{g} / \mathrm{ml})$, L-glutamine $(2$ $\mathrm{mm})$, transferrin $(10 \mu \mathrm{g} / \mathrm{ml})$, sodium selenite $(60 \mathrm{~nm})$, nonessential amino acids $(0.1 \mathrm{~mm})$, and gentamycin $(50 \mathrm{ng} / \mathrm{ml})$. Without mechanically shaking off the top layer of cells as in previous studies (Jensen and Chiu, 1990), the cells were replated at a low density and treated with cytosine arabinoside $(1 \mu \mathrm{m})$ to kill rapidly dividing cells (such as meningeal cells). Thereafter, the cells were passaged repeatedly every 1-2 weeks. During the first month, the majority of the cells were flat and non-process bearing. Stellar, process-bearing cells started to appear with time in culture, and by $2-4$ months following the initial plating, these cells made up roughly half of the cell population. Calcium and sodium imaging experiments usually were performed at this time by plating cells onto poly-L-lysine coated glass coverslips at a low density so that stellar cells and flat cells were spatially separated to allow individual cell imaging.

In some experiments, cells following dissociation were plated directly onto coverslips $\left(20 \times 10^{4} \mathrm{cells} / \mathrm{ml}\right)$, and imaging experiments were performed 1 week later.

\section{Solutions}

Solutions were essentially similar to those used in a previous study (Jensen and Chiu, 1990). The normal Locke's solution bathing cells during fluorescence measurements contained $(\mathrm{mm}) \mathrm{NaCl}, 142 ; \mathrm{KCl}, 5.4$; $\mathrm{CaCl}_{2}, 1.8 ; \mathrm{MgCl}_{2}, 0.8$; glucose, 11 ; HEPES, $10(\mathrm{pH}, 7.4)$. Two types of modified Locke's solution were used: high-K $\mathrm{K}^{+}$(part or all of $\mathrm{NaCl}$ replaced by $\mathrm{KCl}$ ) and $\mathrm{Ca}^{2+}$-free (omitting $\mathrm{Ca}^{2+}$ and adding 2 mM EGTA). Excitatory amino acid agonists and antagonists were added to either normal or modified Locke's solution. Nifedipine and CNQX were made up as a stock solution (100 $\mathrm{mm}$ in dimethylsulfoxide) and added to Locke's solution to yield the working concentration. The volume of the recording chamber was about $300 \mu \mathrm{l}$, and astrocytes under study were superfused continuously with control or test solutions at a fixed rate of about $1 \mathrm{ml} / \mathrm{min}$ (giving an approximate $85 \%$ bath exchange in $30 \mathrm{sec}$ ).

\section{Imaging of $\left[\mathrm{Ca}^{2+}\right]_{\mathrm{i}}$}

Fluo-3. Cells were loaded with fluo-3 (Kao et al., 1989) by incubation in Locke's solution containing fluo-3/AM $(5 \mu \mathrm{M})$ and pluronic $(0.07 \%)$ for $45 \mathrm{~min}$ at room temperature. After incubation, the coverslips con- taining the dye-loaded cells were mounted on a recording chamber (Jensen and Chiu, 1990) and washed continuously in normal Locke's solution for at least $10 \mathrm{~min}$ before beginning fluorescence measurements. The recording chamber was secured tightly on the observation platform of a Nikon Diaphot inverted microscope equipped with mercury-lamp illumination $(75 \mathrm{~W})$ and an FITC filter set. The images were viewed through a $20 \times$ Nikon Appo objective and captured by a silicon-intensifier target tube (SIT) camera (Hamamatsu C-008). In most cells, punctated fluo-3 fluorescence resulting from dye compartmentation within cell cytoplasm was not observed; cells that exhibited detectable dye compartmentation were not used in subsequent analysis. On-line image acquisition and shutter control and off-line analysis were performed with an IMB/AT-based image-processing package (Image-1/AT and Fluorescence Package, Universal Imaging Corp., Pennsylvania). A fluorescence image of the entire field of view of the camera (consisting of 30-60 cells) was acquired every $5 \mathrm{sec}$. Between acquisitions, the shutter between the objective and the mercury lamp was closed to avoid bleaching. Each image was the average of 16 successive vidco framcs $(\approx 30$ frames/sec). Images were written onto a 150 -megabyte hard disk and retrieved later for analysis.

Following Cornell-Bell et al. (1990), agonist-induced changes in $\left[\mathrm{Ca}^{2+}\right]_{\text {, }}$ were reported as changes in fluo-3 fluorescence, and calibrations for $\left[\mathrm{Ca}^{2+}\right]_{i}$ were not made. Fluo-3 has several advantages over all available indicators: it has the largest optical signal per molecule (Kao et al., 1989) and is excited by wavelengths in the visible range, which is potentially less injurious to cells than the UV excitation required of other indicators. The drawback of fluo-3 is a lack of spectral shift on binding $\mathrm{Ca}^{2+}$, making calibrations for absolute $\left[\mathrm{Ca}^{2+}\right]_{i}$ much more difficult than with ratio dyes like fura-2. Fluo-3 is thus ideal for studies in which the emphasis is on changes in $\left[\mathrm{Ca}^{2+}\right]_{i}$ rather than on absolute $\left[\mathrm{Ca}^{2+}\right]_{i}$ levels, as in the present report, in which the goal is to compare the shape of the agonist-induced changes in $\left[\mathrm{Ca}^{2+}\right]_{i}$ in type 1 and type 2 astrocytes. Even though absolute $\left[\mathrm{Ca}^{2+}\right]_{i}$ levels were not reported here, variations in dye concentrations and path length could be corrected for, as in Cornell-Bell et al. (1990), by normalizing the fluo-3 signals against the resting signals, pixel by pixel, before agonist application. The data were computed as $\Delta F / F_{0}$, where $F_{0}$ is the baseline fluorescence calculated as the average of 10 images immediately prior to agonist application and $\Delta F$ is the change in fluorescence following agonist application. Note that the fluorescence signals were corrected for the video system offset before computation of $\Delta F / F_{0}$; this offset, recorded for each experiment, was measured by closing the shutter and measuring the camera signal using the same gain settings as for actual data acquisition. Images of $\Delta F / F_{\mathrm{o}}$ were plotted in pseudocolor (as in Fig. $1 A-D$ ). Time course of changes in $\Delta F / F_{0}$ was obtained by defining a region of interest and calculating the average values of $\Delta F / F_{0}$ inside that region. A typical rcgion consisted of 20-100 pixels, and in most cases the regions were drawn around the cell soma. All fluorescence experiments were performed at room temperature.

Fura-2. In the above measurement, values of $\Delta F / F_{0}$ from different cells would reflect a true difference in $\left[\mathrm{Ca}^{2+}\right]_{i}$ changes only if the resting $\left[\mathrm{Ca}^{2+}\right]_{i}$ is similar. In one set of experiments, the absolute level of resting $\left[\mathrm{Ca}^{2+}\right]_{i}$ was estimated from fura- 2 measurements. Cells were incubated in Locke's solution containing fura-2/AM $(5 \mu \mathrm{M})$ and pluronic $(0.07 \%)$ for $45 \mathrm{~min}$ at room temperature as in previous studies (Jensen and Chiu, 1990). Cells were washed with normal Locke's solution for $10 \mathrm{~min}$ before measurement of resting level. Cells were alternatively excited with 340 and $380 \mathrm{~nm}$ wavelengths, and fluorescence was collected with an oilimmersion UV-F40X objective (Nikon). The emission signals were filtered with a $510-\mathrm{nm}$ narrow-band-pass filter, and 16 frames were averaged for cach wavclength. $\left[\mathrm{Ca}^{3+}\right]_{i}(\mathrm{nM})$ was calculated from the fluorescence ratios (340:380) using the following equation:

$$
\left.\left[\mathrm{Ca}^{2+}\right]_{i}=K_{D}\left[R-R_{\min }\right) /\left(R_{\max }-R\right)\right]\left(F_{0} / F_{s}\right),
$$

where $K_{D}$ is $224 \mathrm{nM}$ and $R$ is the ratio of the fluorescence intensity excited by 340 and $380 \mathrm{~nm}$, after first correcting for background fluorescence. Background fluorescence was measured at the end of each calibration procedure using the residual fluoresence after bath application of a Ca ${ }^{2+}$-free Locke's solution (0 $\mathrm{Ca}^{2}$, 2 mM EGTA) containing $5 \mathrm{mM} \mathrm{MnCl}_{2}$ and $10 \mu \mathrm{M}$ ionomycin (Jensen and Chiu, 1990). $F_{0} / F_{s}$ is the ratio of the 380-nm excitation fluorescence at 0 and saturating $\mathrm{Ca}^{2+}$ levels. $R_{\max }, R_{\min }$, and $F_{0} / F_{s}$ were determined by exposing the dye-loaded cells first to Locke's solution containing $1.8 \mathrm{mM} \mathrm{Ca}^{2+}$ and $10 \mu \mathrm{M}$ ionomycin (saturating the cytoplasmic fura- 2 with $\mathrm{Ca}^{2+}$ ), then to one containing $2 \mathrm{mM}$ EGTA with $\mathrm{Ca}^{2+}$ omitted. Instead of using one set of $R_{\max }, R_{\min }$, and $F_{0} / F_{s}$ values to calibrate $\left[\mathrm{Ca}^{2+}\right]_{i}$ in every cell in the camera 
field, these parameters were measured at the same pixel locations from which $R$ was determined to eliminate possible camera nonuniformity. The average resting $\left[\mathrm{Ca}^{2+}\right]_{i}$ for cells with flat and stellar morphologies was $150 \pm 12 \mathrm{nM}(n=54)$ and $183 \pm 16 \mathrm{nM}(n=81)$, respectively, and these values were not statistically different $(t$ test, $p<0.05)$. Without antibody labeling (see below), we assumed that this reflected a similar resting $\left[\mathrm{Ca}^{2+}\right]_{i}$ in type 1 and type 2 astrocytes.

\section{Imaging of $\left[\mathrm{Na}^{+}\right]_{\mathrm{i}}$}

Cells were incubated in Locke's solution containing the ester form of the sodium indicator dye SBFI/AM $(20 \mu \mathrm{M})$ and pluronic $(0.07 \%)$ for $45 \mathrm{~min}$ at room temperature. The cells were washed and mounted for inlaging using the same excitation wavelengths $(340 / 380 \mathrm{~nm})$, emission filters, and objective as for fura-2 (Harootunian et al., 1989). Each pair of images used in the ratioing was collected every 5-20 sec, and the image at each wavelength was the average of 16 frames. No calibrations of absolute $\left[\mathrm{Na}^{+}\right]_{i}$ were made, and changes in $\left[\mathrm{Na}^{+}\right]_{i}$ were reported simply as ratios (340:380), after correcting for the video system offset in each wavelength as described in the fluo-3 section.

\section{Immunohistochemistry}

Following each $\left[\mathrm{Ca}^{21}\right]_{i}$ experiment, the same cells were labeled with antibodies to distinguish between type 1 and type 2 astrocytes. Immunochemistry was performed at room temperature in the recording chamber, and the resultant fluorescence maps of antibody labeling were captured and processed using the same software package as for $\left[\mathrm{Ca}^{2+}\right]_{i}$ imaging. By being careful not to move the chamber during the labeling procedures, fluorescence images of antibody labeling (corrected for background fluorescence due to cell autofluorescence and residual fluo-3 fluorescence) could be superimposed precisely on the corresponding images of $\left[\mathrm{Ca}^{2+}\right]_{i}$ for classification of response with respect to antigenicity.

Cclls first were surface labeled with $\Lambda 2 B 5$. The cells were washed with a blocking solution (Locke's solution containing 10\% goat serum), followed by incubation in the primary A2B5 antibody (1:2 dilution in blocking solution, $20 \mathrm{~min}$ ), and then washed with Locke's solution ( 5 min). Before application of secondary antibody, the cells were briefly illuminated with the mercury lamp, and a fluorescence image ( 16 videoframe average), viewed through a rhodamine filter cube (Nikon), was captured for background correction. The secondary antibody, rhodamine-coupled $F\left(a b^{\prime}\right)$,-fragment goat anti-mouse IgG, was applied (20 $\mathrm{min}$ ), cells were washed, and another fluorescence image was captured. The difference between these two images reflects A2B5 labeling (see Fig. $1 E$ ). This was followed by intracellular labeling with anti-GFAP. Cells first were fixed at room temperature for $10 \mathrm{~min}$ with ethanol plus $5 \%$ acetic acid (precooled to $-20^{\circ} \mathrm{C}$ ), washed with blocking solution $(5 \mathrm{~min})$, incubatcd in primary GFAP antibody (rabbit IgG, in blocking solution, $20 \mathrm{~min}$ ), and washed $(5 \mathrm{~min})$. A fluorescence image, viewed with the FITC filter, was then recorded. This image typically consisted of residual fluo-3 fluorescence from previous $\left[\mathrm{Ca}^{2}{ }^{2}\right]_{i}$ imaging experiments because GFAP was viewed with a FITC-conjugated secondary body, which utilized the same filter cube as in fluo-3. The secondary antibody, fluorescein-coupled $F\left(a b^{\prime}\right)_{2}$-fragment goat anti-rabbit IgG, was applied (20 $\mathrm{min}$ ), cells were washed, and another fluorescence image was captured. The difference between these images reflects GFAP labeling (Fig. $1 F$ ). Only $\left[\mathrm{Ca}^{2+}\right]_{i}$ responses from cells that still adhered to the coverslip after this double-labeling procedure were included in the analysis; about $30 \%$ of the cells were lost following antibody labeling.

Similar procedures were used in antibody labeling following $\left[\mathrm{Ca}^{2+}\right]_{i}$ imaging experiments.

Criteria for scoring a cell as GFAP positive. Following GFAP labeling, the fluorescence usually increased substantially over the residual fluo-3 fluorescence, allowing fairly unambiguous scoring of a cell as GFAP positive (GFAP'). This increase was examined quantitatively in 103 cells (three experiments): the fluorescence increased by $740 \pm 55 \%(n$ $=103$ ) over the residual fluo-3 fluorescence following GFAP labeling, with $95 \%$ of the cells exhibiting at least $100 \%$ increase. In the case of identifying GFAP-positive cells following $\left[\mathrm{Na}^{+}\right]_{i}$ imaging experiments, any residual SBFI fluorescence should not have contributed to GFAP fluoresence because SBFI, a UV dye (Harootunian et al., 1989), is not excited at the wavelength used to excite the FITC used to view GFAP.

\section{Results}

Simultaneous $\left[\mathrm{Ca}^{2+}\right]_{\mathrm{i}}$ imaging of type 1 and type 2 astrocytes in mixed cultures reveals differential responses to glutamate Figure 1 illustrates both the key observation in this study and the methodology used in arriving at the result. Briefly, a mixed culture from neonatal brain first was subjected to $\left[\mathrm{Ca}^{2+}\right]_{i}$ image analysis (Fig. $1 A-D$ ) in real time and was followed by antibody staining of the same cells (Fig. $1 E, F$ ) for glial identification. Fluorescence signals of fluo-3-loaded cells, normalized against the preagonist signals, are shown in pseudocolor before $(A)$ and $10 \mathrm{sec}(B), 15 \mathrm{sec}(C)$, and $25 \mathrm{sec}(D)$ following a maintained bath application of $500 \mu \mathrm{M}$ glutamate. Qualitatively, two major patterns of response were seen. The first was transient and oscillatory, as illustrated by Figure $1 A$, cells 1 and $2 .\left[\mathrm{Ca}^{2+}\right]_{i}$ increased shortly after glutamate application $(B)$, rcturncd morc or less to baseline $(C)$, then either increased again $(D$, cell 1$)$ or remained near the baseline level $(D$, cell 2$)$. The second pattern of response, in contrast, was nonoscillatory and was characterized by a more or less sustained rise in $\left[\mathrm{Ca}^{2+}\right]_{i}$ throughout the entire period of glutamate exposure (Fig. 1, cells 3-6).

These two patterns of response correlated with the known morphological and antigenic distinctions between type 1 and type 2 astrocytes. All cells were $\mathrm{GFAP}^{+}$(Fig. $1 F$ ) and hence were astrocytes. Double labeling with A2B5 $(E)$ allows a distinction to be made between type 1 [A2B5 negative (A2B5-)] and type $2\left(\mathrm{~A} 2 \mathrm{~B}^{+}\right)$astrocytes (Raff, 1989). By comparing $\left[\mathrm{Ca}^{2+}\right]_{i}$ images (Fig. $1 A-D$ ) with the corresponding antibody images $(E, F)$, it became apparent that cells exhibiting the oscillatory response $(A-D$, cells 1,2$)$ were type 1 astrocytes, in being $\mathrm{GFAP}^{+}$ $(F)$ and $\mathrm{A} 2 \mathrm{~B}^{-}(E)$, as well as having the typical flatlike morphology. Likewise, cclls with the sustaincd response $(A-D$, cells $3,4)$ were type 2 astrocytes, in being $\operatorname{GFAP}^{+}(F)$ and $\mathrm{A} 2 \mathrm{~B}^{+}$ $(E)$, as well as having stellar morphology. The two astrocytic responses are illustrated more clearly by the two rows of timelapse $\left[\mathrm{Ca}^{2+}\right]_{i}$ fluorescence images for cell 1 (oscillatory, type 1) and cell 4 (sustained, type 2) shown at the bottom of Figure 1. Note that, for type 2 astrocytes, glutamate-induced $\left[\mathrm{Ca}^{2+}\right]_{i}$ rise was found on both the cell soma and the fine processes. A small population $(\approx 13 \%)$ of the stellar, GFAP ${ }^{+}$cells $(F$, cells 5,6$)$ were $\mathrm{A}_{2} \mathrm{~B} 5^{-}(E)$. These cells, however, had similar responses to A2B $5^{+}$cells, suggesting that they might be type 2 astrocytes that had lost this surface marker due to culture age.

Time-course plots for $\left[\mathrm{Ca}^{2+}\right]_{i}$ for cells $1-6$, shown in Figure 2 , illustrate the quantitative differences between the two astrocytic responses. For type 1 astrocytes (left column) there was always an initial rapid transient that peaked within the first 10 sec following glutamate application, followed either by multiple oscillations (Fig. 2, cell 1) or a small secondary, less discrete increase (cell 2). Most type 1 astrocytes in this study showed varying degrees of oscillations that were between these two cases. In contrast, the most consistent response in type 2 astrocytes (right column) was a more or less sustained elevation in $\left[\mathrm{Ca}^{2+}\right]_{i}$ that never showed discrete, rhythmic oscillations. Interestingly, the slow rise to this sustained level (cell 4) was, in some cells, preceded by a fast, spike-like transient (cell 3), which resembled the first spike seen in type 1 astrocytes (left column). However, even in the presence of such an initial spike, the overall response was distinguishable from a type 1 response (as in cell 2) in that $\left[\mathrm{Ca}^{2+}\right]_{i}$ in type 2 astrocytes slowly rose again to a level higher than that reached by the first spike ( 201 out of 202 cells). Essentially similar response features were exhibited by the stellar, $\mathrm{GFAP}^{+}$but $\mathrm{A}^{2} \mathrm{B5}^{-}$cells (Fig. 2, cells 5,6). 

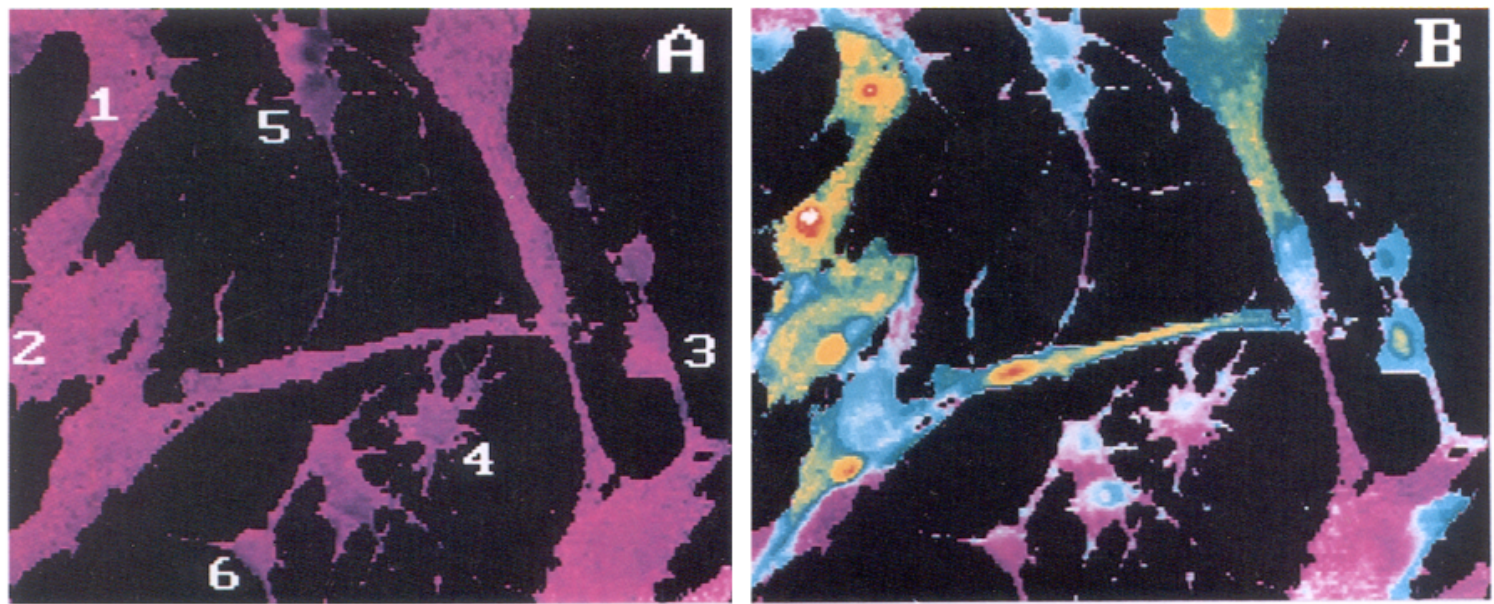

$[400$
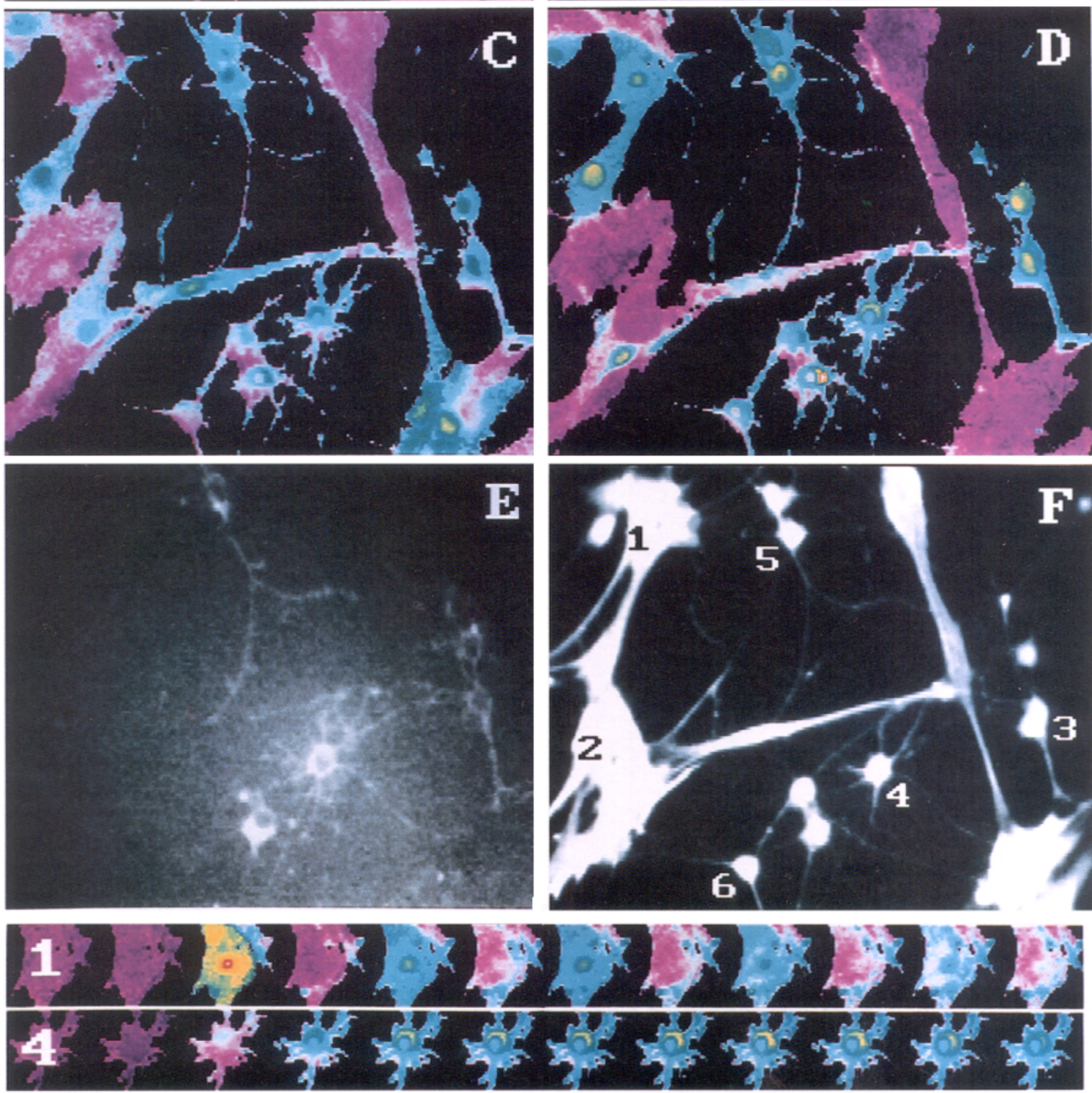

Figure 1. Images of $\left[\mathrm{Ca}^{2+}\right]_{i}(A-D)$ and glial marker labeling $(E, F)$ in the same brain cell culture. $\left[\mathrm{Ca}^{2+}\right]_{i}$ images are expressed as changes in fluo3 fluorescence relative to the resting fluorescence before agonist application $\left(\Delta F / F_{0}\right.$; see Materials and Methods). The fluo-3 images were taken before $(A)$, and $10 \mathrm{sec}(B), 15 \mathrm{sec}(C)$, and $25 \mathrm{sec}(D)$ after changing the bath perfusing solution to one containing $500 \mu \mathrm{M}$ glutamate. The perfusion rate was about $1 \mathrm{ml} / \mathrm{min}$, and the bath volume was about $300 \mu \mathrm{l}$. Following $\left[\mathrm{Ca}^{2+}\right]_{i}$ imaging experiments $(A-D)$, the same cells were labeled with A2B5 $(E)$ and anti-GFAP $(F)$ primary antibodies. Images of glial marker labeling represent fluorescence arising from rhodamine- $(E)$ or FITCconjugated $(F)$ secondary antibodies against the primary antibodies of interest. The same six cells $(1-6)$ are numbered both in the $\left[\mathrm{Ca}^{2+}\right]_{i}(A)$ and the GFAP $(F)$ maps. More frames of time-lapsed fluo-3 images are shown at the bottom for cell $1\left(\mathrm{GFAP}^{+}, \mathrm{A}^{\mathrm{B}} 5^{-}\right) \mathrm{and}^{-}$cell $4\left(\mathrm{GFAP}^{+}\right.$, $\left.\mathrm{A}^{2} \mathrm{~B}^{+}\right)$ to contrast the oscillatory and nonoscillatory nature of the two astrocytic responses; starting from left, images for each row are shown at 10 and 5 sec before glutamate application, and afterwards at 10,30,50,60,75, 90, 105, 120, 135, and 155 sec. 
Type-1 astrocytes

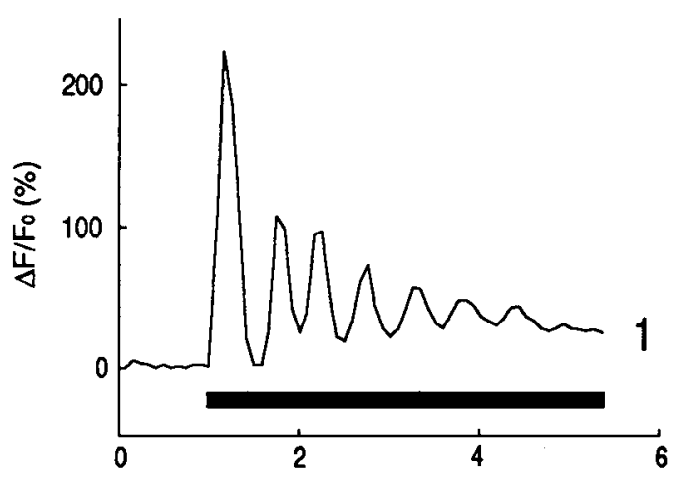

Figure 2. Single-cell $\left[\mathrm{Ca}^{2+}\right]_{i}$, responses elicited by glutamate in type 1 (left) and type 2 (right) astrocytes. Time-course data are plotted from cells $1-6$ of Figure 1. $\left[\mathrm{Ca}^{2+}\right]_{i}$ is expressed as changes in fluo3 fluorescence relative to rest $\left(\Delta F / F_{0}\right)$. Responses were calculated by averaging signals within the cell body region. Cell morphology and antigenicity are flat, $\mathrm{GFAP}^{+}$, and $\mathrm{A}^{2 \mathrm{BS}^{-}}$(cells 1, 2); stellar, $\mathrm{GFAP}^{+}$, and $\mathrm{A}^{2} \mathrm{B5}^{+}$(cells 3,4 ); and stellar, GFAP+, and A2B5- (cells 5, 6). Glutamate $(500 \mu \mathrm{M})$ was bath applied continuously throughout the period indicated by the horizontal bar.

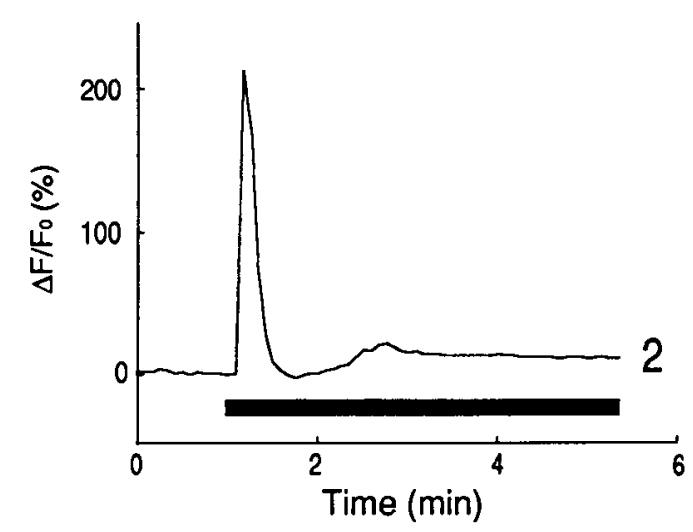

Type-2 astrocytes

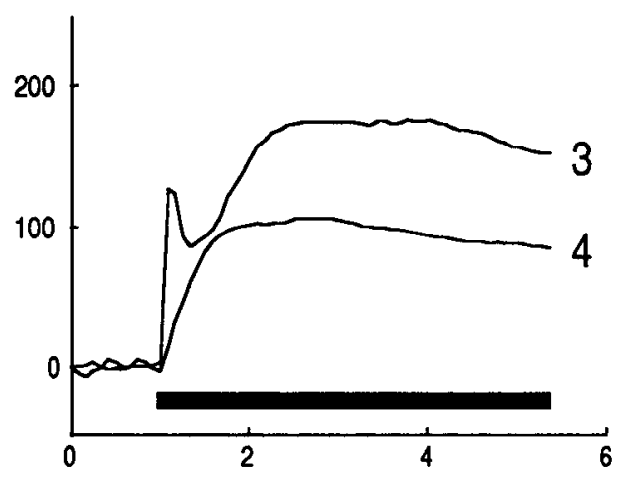

The distinguishing features of the two astrocyte responses (Figs. 1,2) were independent of glutamate concentration, at least in the range of $30-500 \mu \mathrm{M}$ tested. A summary of the results is presented in Table 1. Here, in the oscillatory category, responses were delineated into two groups: those giving only one spike (as in Fig. 2, ccll 2) and those giving multiple spikes (as in Fig. 2, cell 1) during 1.5-5 min of continuous glutamate application. Likewise, in the sustained category, responses were classified as either having (as in Fig. 2, cell 3), or not having (as in Fig. 2, cell 4), a resolvable initial spike before the slow rise to the plateau phase. The corresponding cellular morphology and glial marker antigenicity for each of the responses were evaluated. A strict correlation between glial type and response pattern emerged; oscillatory responses were restricted to type 1 astrocytes, and sustained responses, to type 2 astrocytes. The averages of responses from all cells are shown in Figure 3 for $30 \mu \mathrm{M}, 100 \mu \mathrm{M}$, and $500 \mu \mathrm{M}$ glutamate. Note that rhythmic oscillations, seen in single type 1 astrocytes (Fig. 2, cell 1), are no longer seen in the averaged response because of asychronous oscillations among different cells. The apparent reduction in the size of the first spike for type 1 astrocytes seen when glutamate concentration was increased from 100 to $500 \mu \mathrm{M}$ may be related to the previously reported depression of oscillations when high concentrations (1 mM) were used (Cornell-Bell et al., 1990). Besides recapitulating the key distinctions between the two astrocytic responses, Figure 3 also reveals an additional quantitative distinction; the first spike, though sometimes present in type 2 astrocytes, was smaller than in type 1 astrocytes.

In subsequent analysis, the cell type for each $\left[\mathrm{Ca}^{2+}\right]_{i}$ measurement was antigenically and morphologically identified as type 1 (flat, $\mathrm{GFAP}^{+}$, and $\mathrm{A}^{2 \mathrm{~B} 5} 5^{-}$) or type 2 (stellar, $\mathrm{GFAP}^{+}$, and $\mathrm{A}^{2} \mathrm{B5}^{+}$); the small class of stellar, $\mathrm{GFAP}^{+}$but A2B5- cells (e.g., Fig. 1, cells 5, 6) was excluded.

\section{Short-term cultures}

We examined whether the differential $\left[\mathrm{Ca}^{2+}\right]_{i}$ response in the two astrocyte types observed in cells 1-5 months old (as discussed above) was a reflection of properties that developed with time in culture. Accordingly, cells following dissociation were plated directly onto coverslips, and $\left[\mathrm{Ca}^{2+}\right]_{i}$ measurements were performed 1 week later. Cell phenotypes were antigenically identified as above. Responses were elicited in 11 of 13 type 2 astrocytes and 4 of 10 type 1 astrocytes. The type 2 responses displayed a slow rise to a sustained level and were not preceded by a spikelike transient. The type 1 responses exhibited an initial spikelike transient with little or no subsequent oscillations. Thus, at least qualitatively, the differential responses in the two astrocyte types seen in long-term cultures were already present in 1 -week-old cultures. No further studies were made on these young cultures.

\section{$K A$ and $A M P A$ predominantly elicit $\left[\mathrm{Ca}^{2+}\right]_{\mathrm{i}}$ responses in type 2 astrocytes}

Because glutamate is known to activate both ionotropic and metabotropic classes of receptors (Ascher and Nowak, 1988; Sugiyama et al., 1989), the sensitivity of the two astrocyte types to more specific analogs was examined. The analogs used were $\mathrm{KA}$ (specific for the KA-subtype receptor) and $\alpha$-amino-3-hydroxy-5-methylisoxazole-4-propionate (AMPA; specific for the quisqualate-subtype receptor), both of which have been reported 

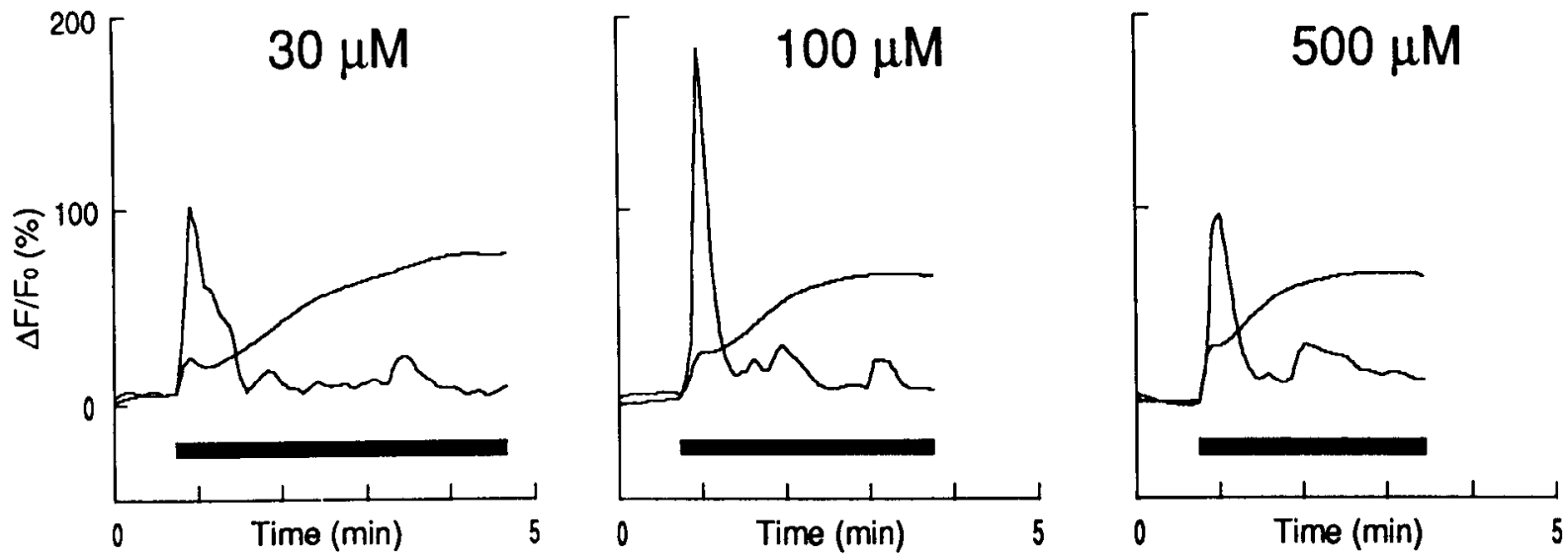

Figure 3. Averaged $\left[\mathrm{Ca}^{2+}\right]_{i}$ responses for type 1 and type 2 astrocytes at different glutamate concentrations. Type 1 responses have the large initial spike, and type 2 responses have a much smaller initial spike and are followed by a prominent secondary slow rise for all concentrations indicated. Glutamate was bath applied during the period indicated by the horizontal bars. All cells included in each average were antigenically identified as type $1\left(\mathrm{GFAP}^{+}\right.$and $\left.\mathrm{A} 2 \mathrm{B5}^{-}\right)$or type $2\left(\mathrm{GFAP}^{+}\right.$and $\left.\mathrm{A}^{2} \mathrm{B5}^{+}\right)$. The numbers of cells in each averaged response for type 1 and type 2 astrocytes, respectively, are $N=28,25$ at $30 \mu M, N=112,98$ at $100 \mu M$; and $N=33,88$ at $500 \mu M$. Only cells with stable preagonist baseline were included. Data were pooled from different cells maintained in culture for $1-5$ months.

to elicit only ionotropic and not metabotropic responses (Sugiyama et al., 1989). By scoring for the percentage of cells that responded to $100 \mu \mathrm{M}$ of agonists, it became clear that, whereas both cell types were sensitive to glutamate (Table 1, Fig. 4A), virtually only the type 2 astrocytes responded with an increase in $\left[\mathrm{Ca}^{2+}\right]$, to analogs specific for the ionotropic receptor (Fig. $4 A)$. The corresponding averaged time course plots of $\left[\mathrm{Ca}^{2+}\right]_{i}$ for the two astrocyte types are shown in Figure $4, B$ and $C$.

The $\left[\mathrm{Ca}^{2+}\right]_{i}$, responses elicited in type 2 astrocytes by KA (Fig. $4 B$ ) and AMPA (Fig. 4C) resembled the responses elicited by glutamate (Fig. $4 D$, control) in displaying a slow rise to a plateau phase. However, the responses (Fig. $4 B, C$ ) almost never exhib-

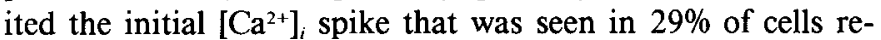
sponding to glutamate (Table 1, Fig. 4D).

Antagonist $C N Q X$ blocks glutamate-induced, sustained $\left[\mathrm{Ca}^{2+}\right]_{\mathrm{i}}$ rise in type 2 astrocytes

Antagonist cxpcriments further suggested that the bulk of the response elicited by glutamate in type 2 astrocytes was mediated by ionotropic glutamate receptors. CNQX, an antagonist for the ionotropic non-NMDA glutamate receptor (Honore et al., 1988), which is ineffective against the metabotropic glutamate receptor
(Sugiyama et al., 1989), was tested in type 2 astrocytes. Figure $4 D$ shows two averaged responses to a bath application of 100 $\mu \mathrm{M}$ glutamate, one in the absence (control) and the other in the presence of CNQX (experiments with 5 and $10 \mu \mathrm{M}$ were pooled). The plateau rise in $\left[\mathrm{Ca}^{2+}\right]_{i}$ was eliminated completely; in contrast, the initial fast spike remained.

Glutamate-induced $\left[\mathrm{Ca}^{2+}\right]_{\mathrm{i}}$ rise is more dependent on external $\mathrm{Ca}^{2+}$ in type 2 than in type 1 astrocytes

To examine the importance of external calcium, cells were incubated with a calcium-free Locke's solution $\left(0 \mathrm{Ca}^{2+}, 2 \mathrm{~mm}\right.$ EGTA) for 3-5 min, followed by addition of $100 \mu \mathrm{M}$ glutamate to the calcium-free solution. Under these conditions, the proportion of type 2 astrocytes that responded markedly decreased from a control value of $85 \%$ to $9 \%$ (Fig. $5 A$ ). Interestingly, most of the cells that responded in $\mathrm{Ca}^{2+}$-free bath solutions showed an initial small $\left[\mathrm{Ca}^{2+}\right]_{i}$ spike even though the secondary plateau phase virtually had disappeared (Fig. $5 B$ ). In contrast, type 1 astrocytes showed significant sensitivity to glutamate in the absence of external calcium (Fig. 5A), even though the $\left[\mathrm{Ca}^{2+}\right.$; responses exhibited much less tendency to oscillate, as noted previously (Cornell-Bell et al., 1990; Jensen and Chiu, 1990).

Table 1. Relation between cell morphology, cell antigenicity, and the form of glutamate-induced $\left[\mathrm{Ca}^{2+}\right]_{i}$ response

\begin{tabular}{|c|c|c|c|c|c|c|c|c|}
\hline \multirow[b]{2}{*}{ Glutamate $(\mu \mathrm{M})$} & \multicolumn{2}{|c|}{ Oscillatory } & \multicolumn{2}{|l|}{ Sustained } & \multirow[b]{2}{*}{ Morphology } & \multicolumn{2}{|c|}{ Antibody } & \multirow[b]{2}{*}{ Number of cells } \\
\hline & Multiple & Single & 1st spike & No spike ${ }^{a}$ & & (GFAP) & (A2B5) & \\
\hline 30 & $61 \%$ & $39 \%$ & $\begin{array}{l}58 \% \\
100 \%\end{array}$ & $\begin{array}{l}42 \% \\
0 \%\end{array}$ & $\begin{array}{l}\text { Flat } \\
\text { Stellar } \\
\text { Stellar }\end{array}$ & $\begin{array}{l}+ \\
+ \\
+\end{array}$ & $\begin{array}{l}- \\
+ \\
-\end{array}$ & $\begin{array}{c}23(28) \\
24(25) \\
1(1)\end{array}$ \\
\hline 100 & $60 \%$ & $40 \%$ & $\begin{array}{l}29 \% \\
8 \%\end{array}$ & $\begin{array}{l}71 \% \\
92 \%\end{array}$ & $\begin{array}{l}\text { Flat } \\
\text { Stellar } \\
\text { Stellar }\end{array}$ & $\begin{array}{l}+ \\
+ \\
+\end{array}$ & $\begin{array}{l}- \\
+ \\
-\end{array}$ & $\begin{array}{c}84(116) \\
104(123) \\
13(19)\end{array}$ \\
\hline
\end{tabular}

${ }^{a}$ As illustrated by Figure $5 B$, a transient response in the type 2 astrocytes could be masked by the sustained response. Thus, this column should actually denote "sustained, no resolvable first spike." This may underestimate the actual percentage.

${ }^{b}$ This column gives the number of cells that responded in each condition; the total number of cells tested is given in parentheses. 

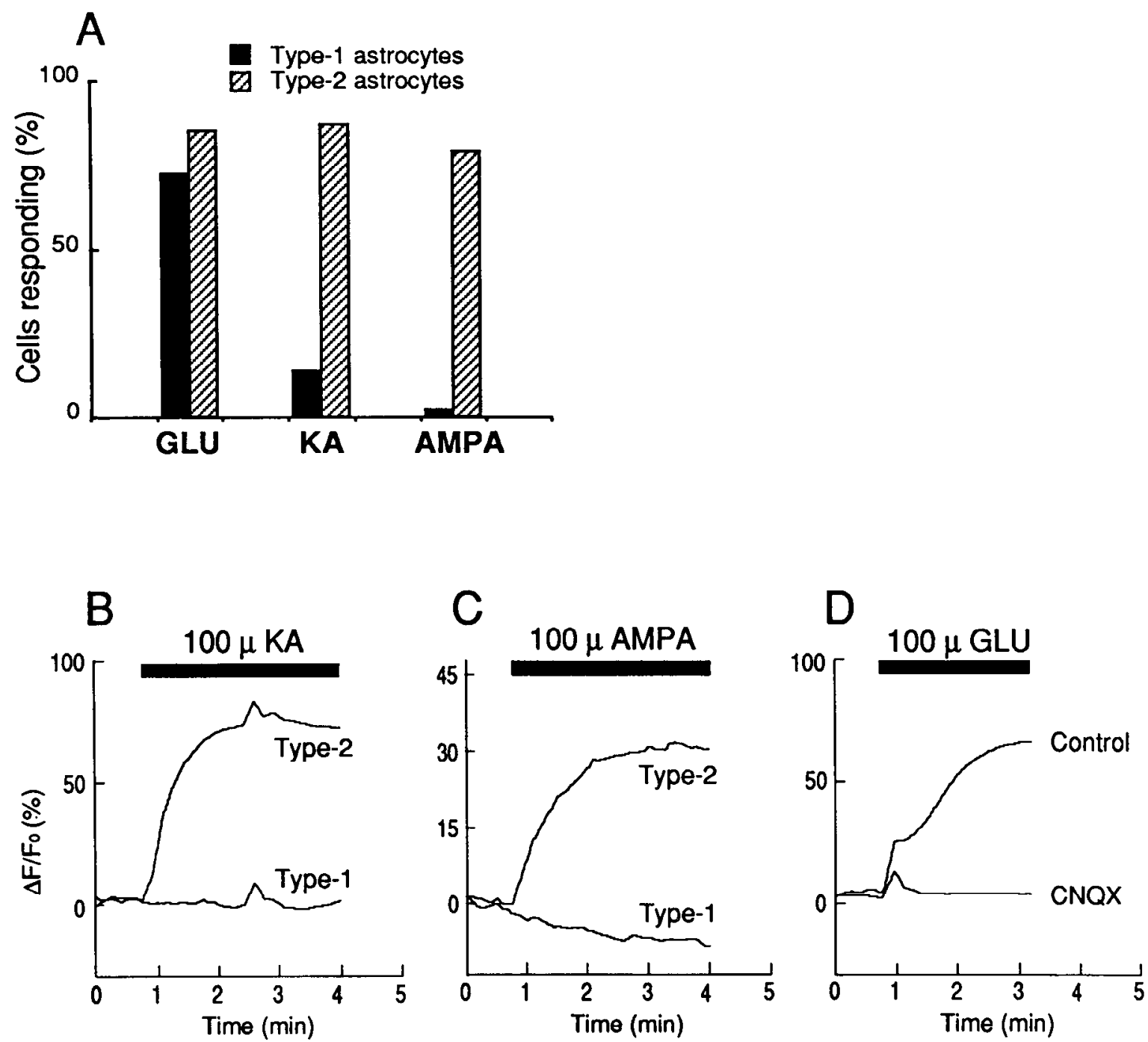

Figure 4. Different sensitivity of the two astrocytic $\left[\mathrm{Ca}^{2+}\right]_{i}$ responses to $100 \mu \mathrm{M}$ of glutamate and analogs. $A$, The percentage of cells that responded to glutamate $(G L U), K A$, and $A M P A$. Only cells with stable preagonist baseline were included; a cell was scored as responding by a rise in fluo-3 signals $\left(\triangle F / F_{0}\right)$ immediately following agonist application. The numbers of cells for type 1 and type 2 astrocytes, respectively, are $N=116,123$ for $G I U ; N=51,78$ for $K A$; and $N=48,42$ for $A M P A$. The corresponding averaged time course plots of responses for KA and AMPA are shown in $B$ and $C . D$. The effect of CNQX on the averaged glutamate response in type 2 astrocytes. Upper trace, control (100 $\mu \mathrm{M}$ glutamate; $N=123$ ); lower trace, CNQX added together with $100 \mu \mathrm{M}$ glutamate $(N=137)$, preceded by a 3-5-min exposure to CNQX alone. The antagonist was used at 5 and $10 \mu \mathrm{M}$, and data were pooled from different experiments. Horizontal bars in $B, C$, and $D$ indicate the duration of agonist application.

Figure $5 B$ shows a type 2 astrocyte experiment in which calcium was added back to the bath while glutamate was being applied continuously. Clearly, this resulted in a large rise in $\left[\mathrm{Ca}^{2+}\right]_{i}$, further supporting the idea that the lack of response in the previous $\mathrm{Ca}^{2+}$-free portion was due simply to a lack of external $\mathrm{Ca}^{2+}$ ions to carry the influx.

The role of voltage-gated calcium channels in glutamate-induced $\left[\mathrm{Ca}^{2+}\right]_{\mathrm{i}}$ rise in type 2 astrocytes

Because glutamate induces membrane depolarization in astrocytes (Bowman and Kimelberg, 1984; Kettenmann et al., 1984), one route for calcium influx is through voltage-gated calcium channels activated secondarily by this depolarization. Indeed, type 2, but not type 1, astrocytes express L-type calcium channels in normal culture medium (for review, see Barres et al., 1990a). The effects of nifedipine (100 $\mu \mathrm{M})$, an L-type calcium channel blocker, was examined in typc 2 astrocytes by first perfusing the bath with glutamate $(100 \mu \mathrm{M})$ to elicit a $\left[\mathrm{Ca}^{2+}\right]_{i}$ responsc. At the peak of the response (2.5 min after glutamate perfusion), nifedipine was added to the perfusing solution. This resulted in an accelerated return of $\left[\mathrm{Ca}^{2+}\right]_{i}$ toward the baseline. When measured at $5.5 \mathrm{~min}$ ( $3 \mathrm{~min}$ after nifedipine application), the $\left[\mathrm{Ca}^{2+}\right]_{i}$ signal was reduced by $27 \pm 1 \%(n=10$ cells $)$ relative to the signal immediately before nifedipine was added. Corresponding measurements at the same time point $(5.5 \mathrm{~min})$ in control glutamate experiments in the absence of nifedipine yielded only an $11 \pm 4 \%(n=14$ cells $)$ reduction. This reduction by nifedipine was significantly different from control $(t$ test, $p$ $<0.01)$.

The presence of voltage-gated calcium channels in type 2 astrocytes was suggested further by the increase in $\left[\mathrm{Ca}^{2+}\right]_{i}$ seen when cells were depolarized by high- $\mathrm{K}^{+}$solutions (Fig. 6). Here, bath application of $147 \mathrm{mM} \mathrm{K}^{+}$-Locke's solution $\left(\mathrm{Na}^{+}\right.$replaced by $\mathrm{K}^{+}$) elicited a $\left[\mathrm{Ca}^{2+}\right]_{i}$ response that was similar to the plateau phase seen in a glutamate response. The major difference was that the $\mathrm{K}^{+}$-induced $\left[\mathrm{Ca}^{2+}\right]_{i}$ rise was monotonic and was never 


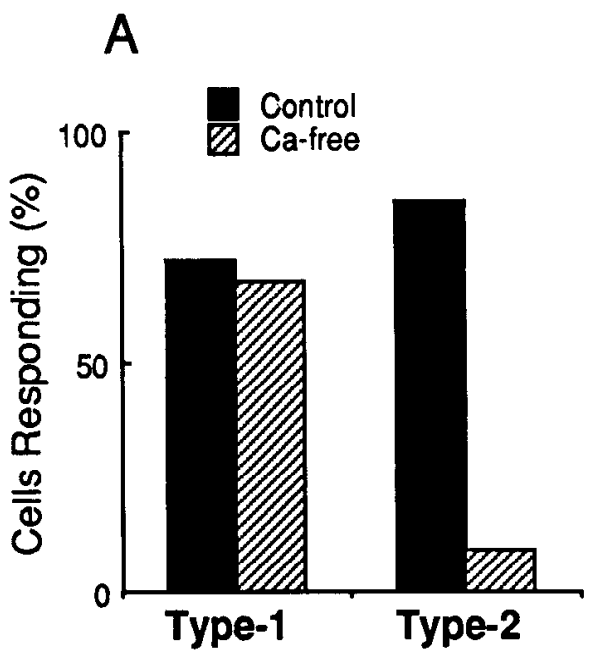

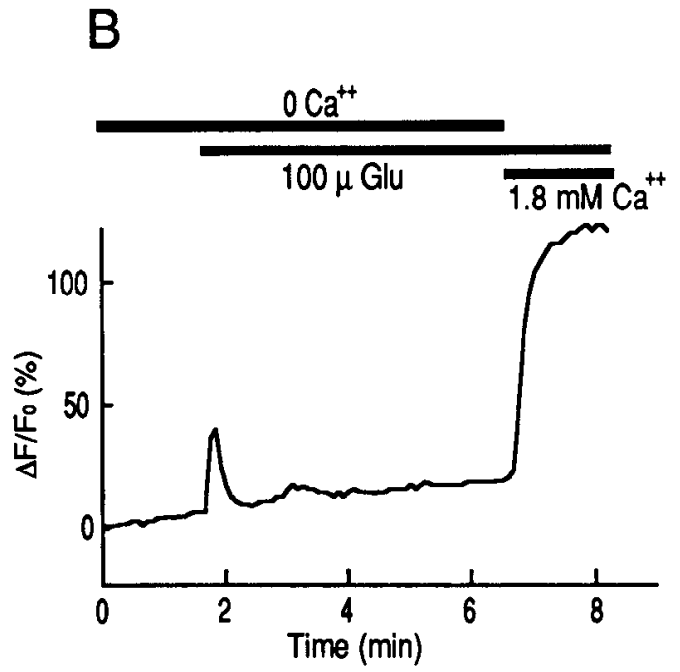

Figure 5. Different sensitivity of the two astrocytic glutamate responses to external calcium. $A$, Percentage of cells responding to $100 \mu \mathrm{M}$ glutamate with calcium $(1.8 \mathrm{~mm})$ or without it $(0 \mathrm{cal}$ cium, 2 mM EGTA) in the bath. In the latter case, cells were incubated in a calcium-free Locke's solution for 35 min before glutamate application. $B$, Single-cell $\left[\mathrm{Ca}^{2+}\right]_{i}$ response in a type 2 astrocyte. Calcium was initially absent from the bath, but reintroduced $(1.8$ $\mathrm{mM}$ ) during a continuous application of $100 \mu \mathrm{M}$ glutamate. preceded by an initial spike. Interestingly, type 1 astrocytes in the same coverslip also showed $\mathrm{a}\left[\mathrm{Ca}^{2+}\right]_{i}$ rise that, in comparison, was transient (Fig. 6). This increase is probably not due to calcium channels because they normally are not present in type 1 astrocytes (for review, see Barres et al., 1990a). It is further unlikely that this $\left[\mathrm{Ca}^{2+}\right]_{i}$ increase was mediated by the $\mathrm{Na}^{+} / \mathrm{Ca}^{2+}$ exchanger because replacement of bath $\mathrm{Na}^{+}$by choline did not result in any increase (Jensen and Chiu, 1990). This increase may be attributable to the formation of IP3 caused directly by depolarization (Larocca et al., 1987). Similar responses were observed in the two astrocyte types when $75-\mathrm{mM} \mathrm{K}^{+}$solutions were used.

\section{Kainate elicits an increase in $\left[\mathrm{Na}^{+}\right]_{\mathrm{i}}$ in type 1 and type 2 astrocytes}

The observation that KA and AMPA elicit $\left[\mathrm{Ca}^{2+}\right]_{i}$ responses only in type 2 astrocytes raises the issue of whether ionotropic receptors are absent in type 1 astrocytes. However, the lack of response in type 1 astrocytes may result from $\mathrm{Ca}^{2+}$-impermeable non-NMDA channels in combination with an absence of voltage-gated calcium channels. Because KA-gated channels are highly permeable to $\mathrm{Na}^{+}$(Ascher and Nowak, 1988; Sontheimer et al., 1988), we took advantage of the recently introduced $\mathrm{Na}^{+}$ fluorescence dye SBFI (Harootunian et al., 1989) to monitor changes in $\left[\mathrm{Na}^{+}\right]_{i}$ following channel activation, which is a more direct indication of the presence of this type of receptor than that offered by measurement of $\left[\mathrm{Ca}^{2+}\right]_{i}$. Figure $7, A$ and $B$, shows that bath application of $\mathrm{KA}(100 \mu \mathrm{M})$ elicited a rise in $\left[\mathrm{Na}^{+}\right]_{i}$ in both types of astrocytes, with the rise being higher in type 2 than in type 1 astrocytes. Tetrodotoxin (TTX; $1 \mu \mathrm{M}$ ) was present in the bath solutions to block voltage-gated sodium channels. In the presence of the antagonist CNQX (experiments with 5 and $10 \mu \mathrm{M}$ were pooled), the $\mathrm{KA}$-induced rise in $\left[\mathrm{Na}^{+}\right]_{i}$ was reduced in both astrocyte types (Fig. $7 A, B$ ). Quantitatively, the reduction was examined by least-square fitting a straight line to the preagonist baseline and calculating the $\left[\mathrm{Na}^{+}\right]_{i}$ change relative to this line at a fixed time after agonist application. The rise in $\left[\mathrm{Na}^{+}\right]_{i}$ signal was reduced by $66 \%$ ( $t$ test, significant at $\left.p<0.093\right)$ relative to the control at $2.4 \mathrm{~min}$ after $\mathrm{KA}$ perfusion for type 1 astrocytes, as compared with a significant reduction by $63 \%$ in type 2 astrocytes ( $t$ test, $p<0.01$ ). Figure $7 C$ shows the portion of the $\left[\mathrm{Na}^{+}\right]_{i}$ response blocked by CNQX in both astrocyte types; the CNQX-sensitive component was clearly larger in the type 2 astrocytes. As regarding the CNQX-insensitive response, which has a slow time course, it seems possible that this could arise from an incomplete antagonism or a component of the $\mathrm{Na}^{+}$ $\mathrm{Ca}^{2+}$ exchanger.

\section{Discussion}

In this article, calcium image analysis and glial-specific antibody labeling were performed in conjunction to compare glutamateinduced $\left[\mathrm{Ca}^{2+}\right]_{i}$ responses in type 1 and type 2 astrocytes in cocultures. While glutamate-induced $\left[\mathrm{Ca}^{2+}\right]_{i}$ responses already have been measured in type 1-enriched cultures (Cornell-Bell et al., 1990; Jensen and Chiu, 1990), correlation of $\left[\mathrm{Ca}^{2+}\right]_{i}$ responses with glial markers, on a cell-by-cell basis, has not been attempted. By performing immunohistochemistry and imaging experiments on the same cells, two distinct $\left[\mathrm{Ca}^{2+}\right]_{i}$ responses linked to glial phenotype were identified in cocultures. One is

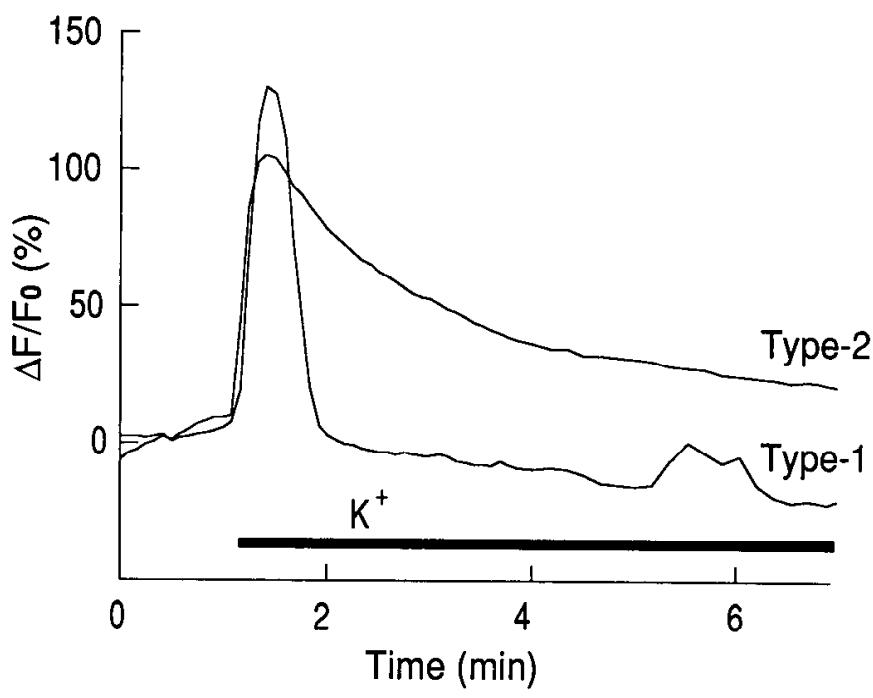

Figure 6. Different effects of high- $\mathrm{K}^{+}$solutions on $\left[\mathrm{Ca}^{2+}\right]_{i}$ in the two astrocyte types. A 147-mM-K $\mathrm{K}^{+}$Locke's solution (equal osmotic substitution of all external $\mathrm{Na}^{+}$by $\mathrm{K}^{+}$) was bath applied as indicated by the horizontal bar. Responses were averaged from 10 type 1 astrocytes and eight type 2 astrocytes in the same coverslip. 

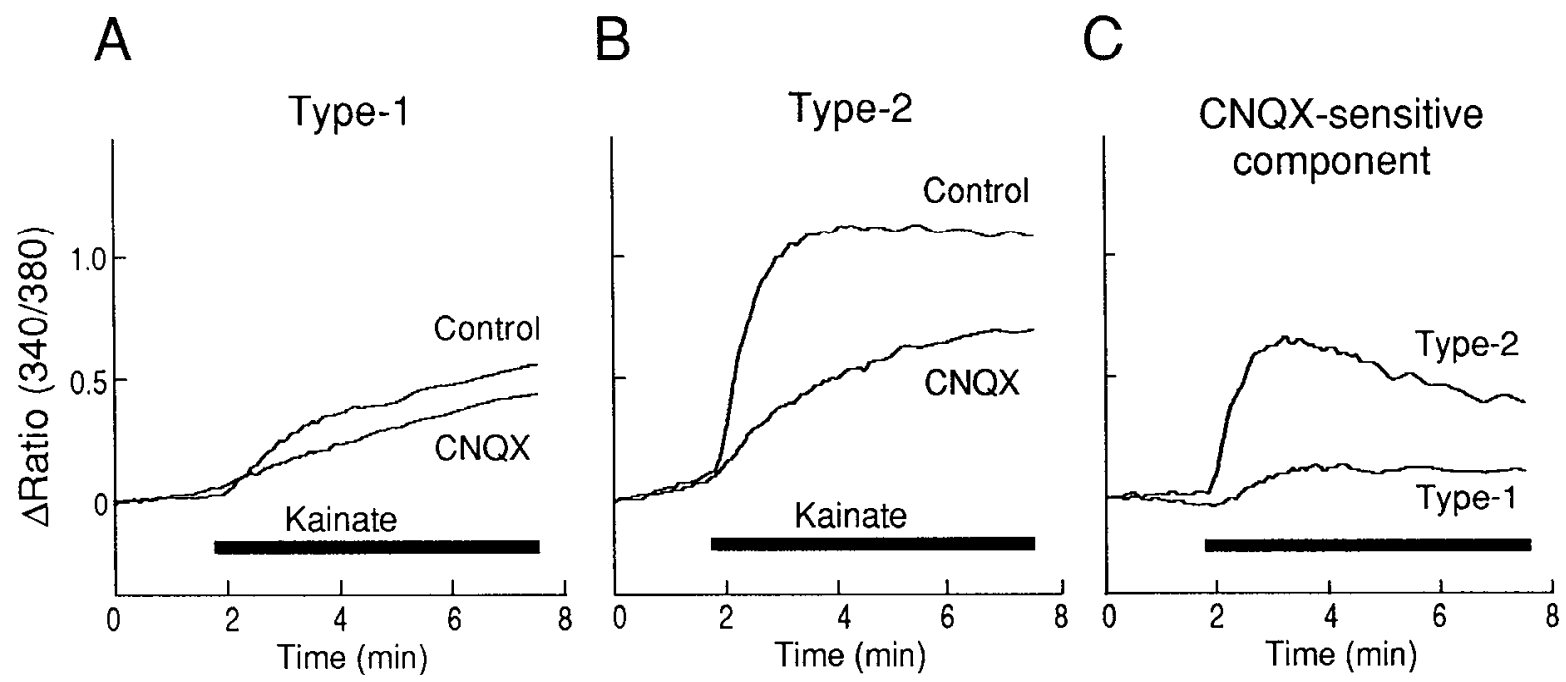

Figure 7. Averaged $\left[\mathrm{Na}^{+}\right]_{i}$ responses induced by $\mathrm{KA}$ in type $1(A)$ and type $2(B)$ astrocytes. The bath was perfused with normal Locke's solution $\left(142 \mathrm{mM} \mathrm{Na}^{+}\right)$to which drugs were added. $A$ and $B:$ upper traces, control (100 $\mu \mathrm{M}$ KA plus $1 \mu \mathrm{M}$ TTX). Lower traces, CNQX added together with $100 \mu \mathrm{M} \mathrm{KA}$, preceded by 1-1.2 min exposure to CNQX alone. $C$, CNQX-sensitive component calculated from $A$ and $B$ by taking the difference between the corresponding control and CNQX traces for each astrocyte type. The antagonist was used at 5 and $10 \mu \mathrm{M}$, and data were pooled from different experiments. Ilorizontal bars indicate the duration of agonist application. Number of cells in each averaged response for type 1 are $N=$ 27 (control) and $N=14$ (CNQX), and for type 2, are $N=12$ (control) and $N=12$ (CNQX). [Na ${ }^{+}$, signals are expressed as the ratio of the emissions at 340- and 380-nm excitation (340:380). Note that the preagonist baseline 340:380 level, computed from the average of 16 images prior to KA application, was subtracted from each corresponding trace so that only changes in 340:380 values are shown. Type 1 and type 2 astrocytes were from the same coverslips in each experiment, and the results were from four coverslips of cells from the same 5-week-old culture.

transient and oscillatory, bearing the hallmark of action of the metabotropic class of glutamate receptor, and could be elicited in both types of astrocytes even though the response is more pronounced in type 1 astrocytes. The other is nonoscillatory and sustained, suggestive of the ionotropic class of glutamate receptors, and was found only in type 2 astrocyles.

\section{Influx and internal mobilization contribute to glutamate-induced $\left[\mathrm{Ca}^{2+}\right]_{\mathrm{i}}$ rise in the two astrocytes}

That internal mobilization contributed to the response in type 1 astrocytes was suggested by the observation that these cells still responded to glutamate in the absence of external calcium (Fig. 5), even though the tendency for oscillations was depressed. This depression of oscillations may be accounted for either by the climination of a calcium influx that normally interacts in some fashion with internal mobilization to yield oscillations, or by a partial depletion of the internal calcium pools during the calcium-free incubation prior to agonist application. Similar observations were obtained in previous studies on type 1 enriched cortical cultures (Cornell-Bell et al., 1990; Jensen and Chiu, 1990).

The plateau phase of the glutamate response in type 2 astrocytes is due to calcium influx, because it was completely abolished when glutamate was applied without calcium present in the bath (Fig. 5B). This influx could be due either to influx through voltage-gated calcium channels activated secondarily by membrane depolarization, and/or via the glutamate-gated ion channel itself. Indeed, recent patch-clamp studies have demonstrated that glutamate activates a channel in type 2 cerebellar astrocytes (Usowicz et al., 1989). However, the channel is coupled to the non-NMDA glutamate receptor subtype, which traditionally is thought to be impermeable to calcium, though two recent studies have suggested that a type of KA-gated channel is more permeable to calcium than previously thought (Murphy and Miller, 1989; Iino et al., 1990). Finally, the observation that nifedipine $(100 \mu \mathrm{M})$ reduced the $\left[\mathrm{Ca}^{2+}\right]_{i}$ response suggests that part of the influx is due to L-type calcium channels; however, we cannot rule out nonspecific actions due to the high concentration of nifedipine used.

The initial $\left[\mathrm{Ca}^{2+}\right]_{i}$ spike in type 2 astrocytes is due to internal mobilization, as suggested by the following observations. First, this spike, unlike the plateau phase that followed, was not completely eliminated in the absence of external calcium (Fig. $5 B$ ). The spike still was found in about $8 \%$ of cells tested with 100 $\mu \mathrm{M}$ glutamate, as compared with $25 \%$ in control (bath $\mathrm{Ca}^{2+}$ present). This reduction in the frequency of observing the first spike may be due to depletion of the internal pool by the 3-5min preincubation in $\mathrm{Ca}^{2+}$-free solution before glutamate application, as discussed earlier regarding the depression of oscillation in type 1 astrocytes. Second, the spike resembles the first spike seen in the oscillatory response in type 1 astrocytes that is presumed to be linked to glutamate-induced IP3 turnover. Indeed, the order of potency of eliciting this spike is glutamate ( $24 \%$ of cells) $\gg \mathrm{KA}(7 \%)>$ AMPA $(0 \%)$ when tested at 100 $\mu \mathrm{M}$, which is similar to that seen in type 1 astrocytes (data not shown), as well as to the relative potency in inducing inositol lipid hydrolysis in cultured cortical astrocytes (Nicoletti et al., 1990). Specifically, AMPA at $1 \mathrm{~mm}$ did not induce detectable inositol phosphate hydrolysis (Nicoletti et al., 1990). Finally, CNQX, a glutamatergic antagonist shown to be ineffective on the metabotropic glutamate receptor, did not block this spike (Fig. 4D).

\section{Ionotropic and metabotropic glutamate receptors in the two types of astrocytes}

Even though glutamate-gated ion channels have been demonstrated electrophysiologically in type 2 astrocytes (Usowicz et al., 1989), evidence for their existence in type 1 cells is so far inconclusive. For example, glutamate-induced whole-cell currents in cerebellar type 1 astrocytes were consistent with a carrier 
mechanism (Cull-Candy et al., 1988), and in type 1 astrocytes from rat optic nerves, whole-cell patch-clamp recordings did not reveal signs of these channels (Barres et al., 1990c). However, in cortical cultures, the macroscopic currents exhibited characteristics of underlying activation of discrete glutamategated channels (Sontheimer et al., 1988). In the present study, two non-NMDA glutamate analogs (KA and AMPA) that are known to activate ion channels in neurons were found to elicit a $\left[\mathrm{Ca}^{2+}\right]_{i}$ response preferentially in type 2 astrocytes. However, the lack of response in type 1 astrocytes may be due to $\mathrm{Ca}^{2+}$ impermeable non-NMDA channels in combination with the absence of voltage-gated calcium channels. Because non-NMDA channels are permeable to monovalent cations like $\mathrm{Na}^{+}$(Ascher and Nowak, 1988; Sontheimer et al., 1988), measurement of $\left[\mathrm{Na}^{+}\right]_{i}$, rather than $\left[\mathrm{Ca}^{2+}\right]_{i}$, may be more appropriate for assaying non-NMDA channel activation. Figure 7 shows that KA induced a rise in $\left[\mathrm{Na}^{+}\right]_{i}$ in both astrocyte types, which was reduced by CNQX. Interestingly, in type 2 astrocytes, the same CNQX concentrations completely eliminated the plateau portion of the glutamate-induced $\left[\mathrm{Ca}^{2+}\right]_{i}$ response (Fig. $4 D$ ) but only partially blocked the $\mathrm{KA}$-induced $\left[\mathrm{Na}^{+}\right]_{i}$ response (Fig. $7 \mathrm{~B}$ ). One explanation is that partial block of a population of non-NMDA channels is sufficient to reduce the membrane depolarization to a degree so that voltage-gated calcium channels are not activated. Another possibility is that the remaining $\left[\mathrm{Na}^{+}\right]_{i}$ rise in CNQX is mediated by a transport mechanism like the $\mathrm{Na}$ /glutamate cotransporter; however, KA is thought not to be a substrate for this transporter (Kimelberg et al., 1989). The size of the CNQXsensitive $\left[\mathrm{Na}^{+}\right]_{i}$ component (Fig. $7 \mathrm{C}$ ), heing larger in type 2 than in type 1 astrocytes, is consistent with a higher density of KAgated channels in the former astrocyte type.

Metabotropic glutamate receptors are best assayed by measuring the second messengers generated intracellulary upon receptor activation, for example, IP3 and calcium. Glutamateinduced liberation of IP3 has been well established in cortical astrocytes (for review, see Pearce and Murphy, 1988). The cortical cultures used in the studies were likely type 1-enriched because most culture procedures were based on the McCarthy and De Vellis (1980) methods. Relatively unexplored is whether type 2 astrocytes express glutamate receptors linked to second messengers. This study suggests that a metabotropic response to glutamate (i.e., the first $\left[\mathrm{Ca}^{2+}\right]_{i}$ spike of Fig. 2, right column) is present in some type 2 astrocytes and that the rcsponsc appcars less robust than in type 1 astrocytes. Thus, the first $\left[\mathrm{Ca}^{2+}\right]_{i}$ spike was much smaller in the type 2 astrocytes (Fig. 3), and discrete $\left[\mathrm{Ca}^{2+}\right]_{i}$ oscillations, a hallmark of IP3-linked receptors (Berridge and Galione, 1988), were never observed superimposed on the plateau phase of the response. Such oscillations are a key feature in the type 1 astrocytic responses (Fig. 2, left; Cornell-Bell et al., 1990; Jensen and Chiu, 1990). Finally, in the absence of external calcium so that only a metabotropic response was elicited, the proportion of type 1 astrocytes responding to glutamate vastly outnumbered type 2 astrocytes (Fig. $5 A$ ). Whether this represents a higher receptor density in type 1 astrocytes or differences in internal calcium pools poses an interesting issue for further studies.

\section{Comparisons with other studies on glutamate-induced $\left[\mathrm{Ca}^{2+}\right]_{\mathrm{i}}$ changes in astrocytes}

In previous studies of cortical astrocytes that were presumably type 1 enriched, significant sensitivity to KA was found (CornellBell et al., 1990; Jensen and Chiu, 1990). In contrast, in this study very few type 1 astrocytes were found to respond to $\mathrm{KA}$
(Fig. $4 A, B$ ). In our previous study on whole populations of cortical astrocytes (Jensen and Chiu, 1990), we raised the possibility that type 2 astrocytes were present to some degree in the type 1 cultures; the results of this study suggest that the reported KA sensitivity in that study may have originated from those contaminating type 2 astrocytes. Another possibility is a difference in culture conditions with regard to cell-cell interactions; in the present study, type 1 astrocytes are less confluent and are cocultured with type 2 astrocytes, whereas in previous studies, type 1 astrocytes are highly purified and confluent (Cornell-Bell et al., 1990; Jensen and Chiu, 1990). Expression of glial receptors, like that demonstrated for voltage-gated ion channels (Corvalan et al., 1990), may be modulated by cell-cell interactions. Furthermore, in this study regional brain differences were not controlled and may contribute to some differences when comparisons are made with studies using astrocytes from known brain regions (Cornell-Bell et al., 1990). However, time in culture does not appear to alter the form of $\left[\mathrm{Ca}^{2+}\right]_{i}$ responses reported here; the differential response in the two astrocyte types (Fig. 2) was already evident in cells cultured for only $7 \mathrm{~d}$ after dissociation, as compared to the majority of the cells, which had been repeatedly passaged for up to 5 months.

\section{Functional implications of glutamate receptors in type 1 and} type 2 astrocytes

Type 1 astrocytes are known to continue to proliferate for at least a week after they develop, but type 2 astrocytes, like neurons, show little if any postmitotic activity once they are formed from precursors (Raff, 1989). Recent studies have suggested a role for neurotransmitters in regulation of astroglial proliferation, in particular, those that activate the receptor class linked to IP hydrolysis. Ashkenazi et al. (1989) have shown that, in cultures of presumably type 1 astrocytes, carbachol stimulates DNA synthesis via muscarinic ACh receptors in a cell-age-dependent fashion. On the other hand, glutamate has been shown to reduce proliferation of cells in type 1-enriched cortical cultures $(\mathrm{Ni}$ coletti et al., 1990). Relatedly, Hatten and co-workers have shown that astroglia proliferation is inhibited by neuronal contact (Hatten, 1987), but a role for trophic factors cannot be ruled out. Astrocytes guide neurons, but unchecked glia proliferation may impede neuron migration and outgrowth. A form of neuronal regulation of astrocyte proliferation may be achieved using glial metabotropic receptors as sensors for neuronal cues (in the form of released glutamate, etc.).

Astrocytes are coupled via gap junctions to form extensive syncytiums in the brain (Gutnick et al., 1981). While the distribution of gap junctions among the two astrocyte types has not been addressed, recent studies suggested that immunoreactivity against a gap-junction protein, connexin 43 , was found extensively along the glial limitans of cerebal cortex (Dermietzel et al., 1989), suggesting that these gap junctions may be a property of type 1 astrocytes. Metabotropic glutamate receptors may be uniquely suitable for long-range signaling in glia syncytium (Cornell-Bell et al., 1990); second messengers generated within one cell (IP3 and calcium) may pass into neighboring cells via second-messenger-permeable gap junctions (Saez et al., 1989). Astrocytes are the major source of glycogen stores in the brain (Cataldo and Broadwell, 1986), and this glial energy reserve may reside in the extensive syncytium. Indeed, neurotransmitterregulated glia glycogen metabolism has been demonstrated (Magistretti, 1988). Second messengers generated consequent to metabotropic receptor activation, like IP3 and calcium, may be involved in the glycogenolytic pathway (Ververken et al., 1982). 
Indeed, the recruitment of metabolic responses via intercellular diffusion of second messengers, as suggested for the gap-junction-coupled liver cells (Saez et al., 1989), may also play a role in mobilizing glial energy reserves in the brain.

It has been demonstrated that excessive exposure to glutamate is toxic to neurons and not to glia (Choi et al., 1987), and it has becn proposed that the toxicity is related to calcium overloading. It has been suggested that glia are protected from this toxicity because the calcium increase elicited by glutamate in type 1 astrocytes is transient and oscillatory (Fig. 2, left) which is less injurious than the sustained increase seen in neurons (Jensen and Chiu, 1990). The observation here that type 2 astrocytes responded with a sustained elevation of calcium (Fig. 2, right), resembling that seen in neurons (Murphy et al., 1987), raises the interesting issue of whether these two brain glia might have different susceptibilities to glutamate toxicity.

\section{References}

Ascher P, Nowak L (1988) Quisqualate and kainate-activated channels in mouse central neurones in culture. J Physiol (Lond) 399:227-245.

Ashkenazi A, Ramachandran J, Capon DJ (1989) Acetylcholine analogue stimulates DNA synthesis in brain-derived cells via specific muscarine receptor subtypes. Nature 340:146-150.

Barres BA, Chun LLY, Corey DP (1989) Glial and neuronal forms of the voltage-dependent sodium channel: characteristics and cell-type distribution. Neuron 2:1375-1388.

Barres BA, Chun LLY, Corey DP (1990a) Ion channels in vertebrate glia. Annu Rev Neurosci 13:441-474.

Barres BA, Koroshetz WJ, Swartz KJ, Chun LLY, Corey DP (1990b) Ion channel expression by white matter glia: the O-2A glial progenitor cell. Neuron 4:507-524.

Barres BA, Koroshetz WJ, Chun LLY, Corey DP (1990c) Ion channel expression by white matter glia: the type-1 astrocyte. Neuron 5:527544.

Berridge MJ, Galione A (1988) Cytosolic calcium oscillators. FASEB J 2:3074-3082.

Bowman CL, Kimelberg HK (1984) Excitatory amino acids directly depolarize rat brain astrocytes in primary culture. Nature 311:656659.

Cataldo AM, Broadwell RD (1986) Cytochemical identification of cerebral glycogen and glucose-6-phosphatase activity under normal and experimental conditions: I. Neurons and glia. J Electron Microsc Technol 3:413-437.

Choi DW, Maulucci-Gedde M, Kriegstein AR (1987) Glutamate neurotoxicity in cortical cell culture. J Neurosci 7:357-368.

Cornell-Bell AH, Finkbeiner SM, Cooper MS, Smith S.I (1990) Glutamate induces calcium waves in cultured astrocytes: long-range glial signaling. Science 247:470-473.

Corvalan V, Cole R, De Vellis J, Hagiwara S (1990) Neuronal modulation of calcium channel activity in cultured rat astrocytes. Proc Natl Acad Sci USA 87:4345-4348.

Cull-Candy SG, Howe JR, Ogden D (1988) Noise and single channels activated by excitatory amino acids in rat cerebellar granule neurones. J Physiol (Lond) 400:189-222.

Dermietzel R, Traub O, Hwang TK, Beyer E, Bennett MLV, Spray DC, Willecke K (1989) Differential expression of three gap junction proteins in developing and mature brain tissues. Proc Natl Acad Sci USA 86:10148-10152.

Gallo V, Giovannini C, Suergiu R, Levi G (1989) Expression of excitatory amino acid receptors by cerebellar cells of the type-2 astrocyte lineage. J Neurochem 52:1-9.

Gutnick MJ, Connors BW, Ransom BR (1981) Dye-coupling between glial cells in the guinea pig neocortical slice. Brain Res 213:486-492.

Harootunian AT, Kao JPY, Eckert BK, Tsien RY (1989) Fluorescence ratio imaging of cytosolic free $\mathrm{Na}^{+}$in individual fibroblasts and lymphocytes. J Biol Chem 264:19458-19467.

Hatten ME (1987) Neuronal inhibition of astroglial cell proliferation is membrane mediated. J Cell Biol 104:1353-1360.

Honore T, Davies SN, Drejer J, Fletcher EJ, Jacobsen P, Lodge D,
Nielsen FE (1988) Quinoxalinediones: potent competitive nonNMDA glutamate receptor antagonists. Science 241:701-703.

Iino M, Ozawa S, Tsuzuki K (1990) Permeation of calcium through excitatory amino acid receptor channels in cultured rat hippocampal neurones. J Physiol (Lond) 424:151-165.

Jensen A, Chiu SY (1990) Fluorescence measurement of changes in intracellular calcium induced by excitatory amino acids in cultured cortical astrocytes. J Neurosci 10:1165-1175.

Kao JPY, Harootunian AT, Tsien RY (1989) Photochemically generated cytosolic calcium pulses and their detection by fluo-3. J Biol Chem 264:8179-8184.

Keinanen K, Wisden W, Sommer B, Werner P, Herb A, Verdoorn TA, Sakmann B, Seeburg PH (1990) A family of AMPA-selective glutamate receptors. Science 249:556-560.

Kettenmann H, Backus KH, Schachner M (1984) Aspartate, glutamate and $\gamma$-aminobutyric acid depolarize cultured astrocytes. Neurosci Lett 52:25-29.

Kimelberg HK, Pang S, Treble DH (1989) Excitatory amino acid-stimulated uptake of ${ }^{22} \mathrm{Na}^{+}$in primary astrocyte cultures. J Neurosci 9:1141-1149

Kuffler SW, Nicholls JG, Martin AR (1984) Physiology of neuroglial cells. In: From neuron to brain, pp 323-360. Sunderland, MA: Sinauer.

Larocca JN, Cervone A, Ledeen RW (1987) Stimulation of phosphoinositide hydrolysis in myelin by muscarinic agonist and potassium. Brain Res 436:357-362.

Magistretti PJ (1988) Regulation of glycogenolysis by neurotransmitters in the central nervous system. Diabete Metab 14:237-246.

McCarthy KD, De Vellis J (1980) Preparation of separate astroglial and oligodendroglial cell cultures from rat cerebral tissue. J Cell Biol 85:890-902.

Murphy SN, Miller RJ (1989) Regulation of $\mathrm{Ca}^{++}$influx into striatal neurons by kainic acid. J Pharmacol Exp Ther 249:184-193.

Murphy SN, Thayer AA, Miller RJ (1987) The effects of excitatory amino acids on intracellular calcium in single mouse striatal neurons in vitro. J Neurosci $7: 4145-4158$.

Nicoletti F, Magri G, Ingrao F, Bruno V, Catania MV, Dell'Albani P, Condorelli DF, Avola R (1990) Excitatory amino acids stimulate inositol phospholipid hydrolysis and reduce proliferation in cultured astrocytes. J Neurochem 54:771-777.

Pearce B, Murphy S (1988) Neurotransmitter receptors coupled to inositol phospholipid turnover and $\mathrm{Ca}^{2+}$ flux: consequences for astrocyte function. In: Glial cell receptors (Kimelberg HK, ed), pp 197 221. New York: Raven.

Raff MC (1989) Glial cell diversification in the rat optic nerve. Science 243:1450-1455.

Saez JC, Connor JA, Spray DC, Bennett MVL (1989) Hepatocyte gap junctions are permeable to the second messenger, inositol 1,4,5-trisphosphate, and to calcium ions. Proc Natl Acad Sci USA 86:27082712.

Somogyi P, Eshhar N, Teichberg VI, Roberts JDB (1990) Subcellular localization of a putative kainate receptor in Bergmann glial cells using a monoclonal antibody in the chick and fish cerebellar cortex. Neuroscience 35:9-30.

Sontheimer H, Kettenmann H, Backus KH, Schachner M (1988) Glutamate opens $\mathrm{Na}^{+} / \mathrm{K}^{+}$channels in cultured astrocytes. Glia 1:328336.

Sontheimer H, Trotter J, Schachner M, Kettenmann H (1989) Channel expression correlates with differentiation stage during the development of oligodendrocytes and their precursor cells in culture. Neuron 2:1135-1145.

Sugiyama H, Ito I, Watanabe M (1989) Glutamate receptor subtypes may be classified into two major categories: a study on Xenopus oocytes injected with rat brain mRNA. Neuron 3:129-132.

Usowicz MM, Gallo V, Cull-Candy SG (1989) Multiple conductance channels in type- 2 cerebellar astrocytes activated by excitatory amino acids. Nature 339:380-383.

Ververken D, Van Veldhoven PV, Proost C, Carton H, DeWulf $H$ (1982) On the role of calcium ions in the regulation of glycogenolysis in mouse brain cortical slices. J Neurochem 38:1286-1295.

Wilkin GP, Marriott DR, Cholewinski AJ (1990) Astrocyte heterogeneity. Trends Neurosci 13:43-46. 